\title{
Using Aplia In Finance Classes: Student Perspectives And Performance
}

\author{
R. Daniel Pace, University of West Florida, USA
}

\begin{abstract}
The author, an early adopter of Aplia, describes the use of Aplia both pre- and post-acquisition by Cengage Learning. Students improve their exam scores (by 5 to 7 percent) and are receptive to using Aplia. Students report despite spending between 7 and 9 hours a week on Aplia assignments, they would gravitate to future offerings that included Aplia assignments.
\end{abstract}

Keywords: Education, Pedagogy, Technology, Aplia

\section{INTRODUCTION}

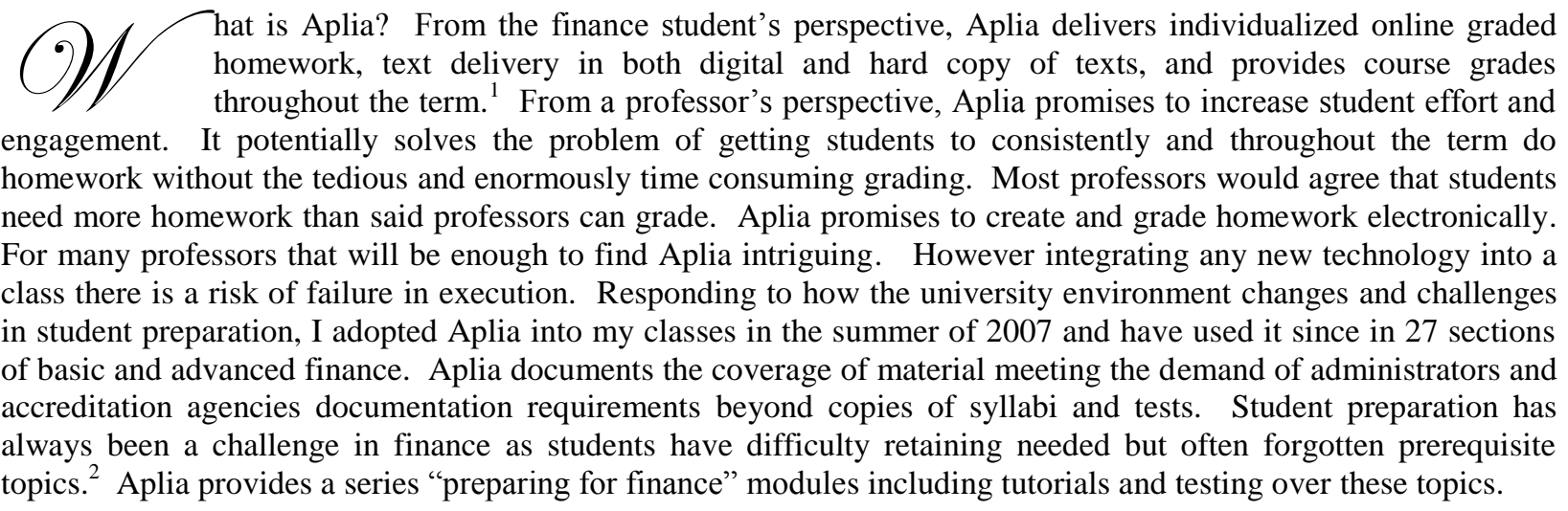

\section{A VERY BRIEF HISTORY OF APLIA}

Aplia's own corporate documents provide an extensive history and philosophy of Aplia that is beyond the scope of this paper. ${ }^{3}$ The salient facts are that in the 1990s Paul Romer wanted to assign more homework but ran into the familiar time grading restraints. He wanted to engage his class with experiments, do more homework, and ultimately have a superior outcome. With co-founded Scott McCrae, Aplia launches its initial product, Principles of Microeconomics. The topical areas expanded, integrated textbooks followed, and in 2007 Cengage Learning acquired Aplia Inc. and the topical areas ${ }^{4}$ and integrated textbook solutions ${ }^{5}$ have vastly broadened. ${ }^{6}$

\footnotetext{
${ }^{1}$ The finance products are more embryonic than economics, with more experiments and news analyses than finance.

2 Topics included in Preparing for finance includes review and testing in Mathematics, Economics, Accounting, and Statistics, which can be used in whole or part.

3 (Aplia)

${ }^{4}$ The current (as of Fall 2010) topical area include: Accounting, Business Communication, Business Law, Decision Sciences, Developmental English, Economics, Finance, History, Management, Marketing, Philosophy, Political Science, Psychology, Statistics, and Taxation

${ }^{5}$ Intergraded books in finance include Ehrhardt and Brigham Corporate Finance; Graham, Smart, Megginson Corporate Finance Financial Management; Besley and Brigham Essentials of Managerial Finance, Besley and Brigham - CFIN Brigham and Ehrhardt Financial Management: Theory and Practice; Brigham and Houston - Fundamentals of Financial Management ; Brigham and Houston Fundamentals of Financial Management, Concise Edition; Megginson and Smart Introduction to Corporate Finance; Megginson and Smart Introduction to Financial Management, International Edition.
} 
The major competitor to Aplia is My Finance Lab. Aplia's finance textbooks are currently focused around the Brigham author and the Graham, Smart, Megginson author teams. My Finance Lab finance text books are built largely around Gitman, Keown, and Madura. ${ }^{7}$

\section{ACADEMIC LITERATURE ON APLIA}

The academic literature on Aplia is limited and generally confined to economics. Caplan and Gilbert (2008) use Aplia to examine student behavior finding that procrastinators are poor performers compared to students who do not procrastinate. Nguyen and Trimarchi (2009) find that the use of Aplia increases the course average by about 2\%, and that students perceive more academic and economic value when Aplia is a higher percentage component in the final grade. In contrast to my findings students spent between 1 and 3 hours on Aplia. Kennelly, Considine and Flannery (2010) find that students report that Aplia is beneficial. Most interestingly, students report that cooperation benefits themselves, but express concerns that other students are cheating when cooperating.

Other, more general literature on technology in the classroom, include Sosin et. al. (2004) who find that technology is a small but significant contribution to student performance. Note that the technology in the study is very broadly defined and while crossing 30 institutions, is not the customized and individualized homework that Aplia delivers. Brown and Liedholm (2004) ask a more basic question - can a virtual online course replace a live or hybrid microeconomics course? Despite have better characteristics (as measured by ACT and credit hours completed) the virtual students performed significantly worse than live students on a standard exam. When asked definition and recognition questions, there were no significant differences across live, hybrid and virtual classes, but when asked application questions, live classes significantly outperformed virtual and hybrid classes.

\section{APLIA EXPERIENCE PRIOR TO CENGAGE}

While the acquisition of Aplia by Cengage occurred in 2007, the integration of specific textbooks as exists now did not happen until 2009 and continues to expand today. Prior to specific text tie-ins offered today, the Aplia finance modules were generic, and still exist today under the listing "Other Books". Each topical area has two assignments "I" and "II" where "I" is the teaching set and "II" is the testing set-for example "Capital Budgeting I" and "Capital Budgeting II." As expected, differences in notation, terminology, content order exist between this general set and any text. A frequent comment by my students was that that Aplia did not always match or seemed different than the text. Students were receptive to the product and more importantly grades on exams improved (between 5 and 7 percent). I did make myself available to help students on Aplia assignments and allowed students to cooperate. The most pleasing result was that since students had a timetable and each student had individualized questions (again this is generally a numerical change in the problem), students were forced to engage the material and in turn, they engaged me resulting in a highly satisfying teaching experience.

\section{APLIA EXPERIENCE AFTER CENGAGE}

As of the spring of 2010, Aplia offered finance modules that were dedicated to specific texts rather than the generic modules of the past. I adopted Brigham and Houston (2009) for a basic introductory finance class and Graham, Smart, and Megginson (2009) for a senior theory and practice class. The term became a tale of two classes - one that worked well and one were the Aplia had significant technological problems. Since Aplia relies on an algorithm to generate individual (or at least create a series of sets) for each individual problem set questions and available answers must align. Simply stated, appropriate and correct answers must be available for the students to choose. I experienced very little of these problems prior using the generalized sets and if I had an issue with

\footnotetext{
${ }^{6}$ (Aplia)

${ }^{7}$ Gitman, Principles of Managerial Finance, Brief $5^{\text {th }}$ editions (2010); Gitman, Principles of Managerial Finance, $12^{\text {th }}$ edition (2009); Keown, Personal Finance: Turning Money into Wealth, $5^{\text {th }}$ edition (2010); Madura, Personal Finance, $4^{\text {th }}$ editions (2011); Gitman and Joehnk, Fundamentals of Investing, $10^{\text {th }}$ edition (2008); Berk, DeMarzo, and Harford, Fundamentals of Corporate Finance, $1^{\text {st }}$ edition (2009); Keown, Foundations of Finance, $6^{\text {th }}$ edition (2008 ); Brooks, Financial Management: Core Concepts, 1 st (2010) Berk and DeMarzo, Corporate Finance: The Core, $2^{\text {nd }}$ edition (2011); Welch, Corporate Finance: An Introduction, $1^{\text {st }}$ edition (2009); Berk and DeMarzo, Corporate Finance, $2^{\text {nd }}$ edition (2010).
} 
wording or anything else about questions, Aplia's support staff quickly and efficiently resolved the problem. The Brigham and Houston (2009) Aplia set (hereafter functioning) was clean with few issues. The Graham, Smart, and Megginson (2009) Aplia set (hereafter nonfunctioning) had severe issues with rarely a chapter set without at least one and often multiple incorrect answers as the only available options. The issues were exasperated by inconsistent formatting within individual questions. For example the first answer pertaining to an information set requiring two decimal precision and the next answer using the same information set requiring four decimal precision - if the entered answer did not conform to requested precision, the answer is graded incorrect. To clarify the problem, if, for example Aplia created 10 versions of a particular problem-answer set many were indeed correct, but a significant minority was incorrect. The Aplia failures increased with the sophistication of the material.

Students complained that they had paid to beta-test the product. My response, in an effort to salvage a poor situation, was to give students a point-bounty when documenting Aplia errors and demonstrating the correct answer. To Aplia's credit, when alerted about an issue, they immediately assigned a case number and forwarded to their content team and there was often a resolution within several days. They were never able to get ahead of the pace of the class so we encountered issues throughout the term. Again to Aplia's credit they refunded all the students costs on the $14^{\text {th }}$ week of the term.

\section{STUDENT ACCEPTANCE AND REACTION TO APLIA}

Given these two classes, we have an opportunity to observe what may approach the boundaries of student opinions given the performance of Aplia. Table 1 compiles the results of the student surveys of the functioning and nonfunctioning classes. Focusing first on the functioning class, I find significant differences (using Chi-Square) that students believe that Aplia increases comprehension (Q1), and expected course grade (Q7) - not surprising as in these classes Aplia counted for 30 percent of the course grade. Students agreed that Aplia assignments substituted for traditional class time (Q2) and that professors should spend time helping students with Aplia assignments (Q4).

The students with nonfunctioning aplia agreed that professors should spend class time helping with Aplia assignments. The nonfunctioning and functioning Aplia classes agreed that collaboration with other students enhanced the Aplia experience (Q5). The nonfunctioning class expectantly did not see Aplia as a substitute for traditional lectures $(\mathrm{Q} 3)$. The final question is particularly interesting as the functioning class agreed that Aplia provides sufficient training in using a financial calculator $(\mathrm{Q} 8)$ while the nonfunctioning class shows no difference of opinion because the training and testing modules were the same for both classes. I can only interpret this result as a frustration with Aplia by the nonfunctioning class. Table 2 shows the student's willingness to take future Aplia hybrid classes if given a choice between traditional and Aplia hybrid offerings. The functioning Aplia class students gravitate to future Aplia hybrid offerings. Surprisingly, the nonfunctioning Aplia class did not overwhelmingly reject future Aplia offerings.

\section{CORRELATING APLIA AND STUDENT SUCCESS}

The correlation coefficients are positive between exam scores and Aplia. Depending on how the data is handled the coefficients range from approximately .5 to .7 (the .7 includes all students, the .5 excludes students who eventually dropped the class). The correlation coefficients must be observed with caution as causality cannot be established through these measures and the association detected may simply be that good students are high performers. My students report spending on average between 9 and 12 hours on Aplia assignments (see Table 3), however observing my students in computer labs, this estimate even if correct, would not represent a focused time on Aplia. Anecdotally, I observe that the less disciplined and likely unsuccessful student does tend to withdraw from Aplia courses early—which may in of itself, justify its use. 
Table 1: Student Survey Reponses to Aplia Hybrid Class

\begin{tabular}{ll}
\hline Q1 & Aplia increases my comprehension of the material. \\
& Functioning \\
& Nonfunctioning
\end{tabular}

Q2 Aplia assignments substitute for traditional class time.

Functioning

Nonfunctioning

Q3 Aplia reduces the need for traditional lectures.

Functioning

Nonfunctioning

Q4 Professors should spend class time helping students with assignments.

Functioning

Nonfunctioning

Q5 Aplia increased my interaction with my professor.

Functioning

Nonfunctioning

Q6 Collaborating with other students enhanced my Aplia experience.

\section{Functioning}

Nonfunctioning

Q7 I will get a better course grade because of Aplia.

$$
\text { Functioning }
$$

Nonfunctioning

Q8 Aplia sufficiently trained me to use a financial calculator.

$$
\text { Functioning }
$$

Nonfunctioning

\begin{tabular}{ccc}
$\mathbf{A}$ & $\mathbf{N}$ & $\mathbf{D}$ \\
\hline$\%$ & $\%$ & $\%$ \\
$92.10^{* *}$ & 2.60 & 5.20
\end{tabular}

\begin{tabular}{ccc}
$\%$ & $\%$ & $\%$ \\
$92.10^{* *}$ & 2.60 & 5.20 \\
47.60 & 33.30 & 19.10 \\
& & \\
$60.50^{* *}$ & 7.90 & 31.60 \\
19.10 & 28.60 & 52.40 \\
& & \\
31.60 & 23.70 & 44.80 \\
19.10 & 18.20 & $72.80^{* *}$ \\
& & \\
$89.40^{* *}$ & 7.90 & 2.60 \\
$72.70^{* *}$ & 18.20 & 9.10 \\
& & \\
42.20 & 31.60 & 26.30 \\
45.40 & 27.30 & 27.20 \\
& & \\
$47.30^{* *}$ & 47.40 & 5.20 \\
$68.20^{* *}$ & 18.20 & 13.60 \\
& & \\
$76.30^{* *}$ & 13.20 & 10.50 \\
40.90 & 22.70 & 36.40 \\
$84.20^{* *}$ & 7.90 & 7.90 \\
45.50 & 31.80 & 22.70 \\
\hline
\end{tabular}

Functioning is defined as the Aplia algorithm working properly creating questions with correct answers available as choices $(\mathrm{N}=38)$

Nonfunctioning is defined as the Aplia algorithms working improperly creating questions without correct answers available as choices $(\mathrm{N}=22)$

${ }^{* * *}$ Significant at the $1 \%$ level that the categories Agree (A), Neutral (N) and Disagree (D) are different.

Table 2: Student Responses to Future Aplia Demand

\begin{tabular}{lcc}
\hline $\begin{array}{l}\text { Given a choice of identical offerings (including the same exams), one class with Aplia } \\
\text { counting } 30 \% \text { of the final grade, and the other class with only traditional exams, which } \\
\text { one would you choose? }\end{array}$ & $\begin{array}{c}\text { Traditional } \\
\%\end{array}$ & $\begin{array}{c}\text { Aplia } \\
\%\end{array}$ \\
\hline Functioning & 15.80 & $84.20 *$ \\
Nonfunctioning & 45.50 & 54.50 \\
\hline Functioning is defined as the Aplia algorithms working properly creating questions with correct answers available as choices \\
$(\mathrm{N}=38)$ \\
$\begin{array}{l}\text { Nonfunctioning is defined as the Aplia algorithms working improperly creating questions without correct answers available as } \\
\text { choices }(\mathrm{N}=22)\end{array}$ \\
${ }^{* * *}$ Significant at the $1 \%$ level that traditional and Aplia are different.
\end{tabular}

Table 3: Student Self-Reported Aplia Weekly Hourly Time

\begin{tabular}{lcccc}
\hline & Average & Median & Standard Deviation & Skewness \\
\hline Functioning & 9.225806 & 6 & 5.925705 & 0.437884 \\
Nonfunctioning & 11.56522 & 16 & 5.774758 & -0.223140 \\
\hline
\end{tabular}

Functioning is defined as the Aplia algorithms working properly creating questions with correct answers available as choices $(\mathrm{N}=38)$

Nonfunctioning is defined as the Aplia algorithms working improperly creating questions without correct answers available as choices $(\mathrm{N}=22)$ 


\section{FUTURE RESEARCH AND CONCLUSION}

Brown and Liedholm (2004) and the response to the question concerning calculator training (Q8) indicate future research. Future research should attempt to understand what concepts and applications can be exported to Aplia (or similar product) and what concepts and applications could benefit by spending additional class contact hours that have been freed.

Does Aplia deliver as promised? My experience is that it does. Students have improved exam performance from between 5 and 7 percent. Aplia does engage students early and throughout the term. When working properly, Aplia is attractive to students and improves their success. After three years I have had only one poor experience with Aplia, which, in my opinion, was simply pushing the product to market early. Aplia's support is outstanding and responsive. Finally I am not affiliated with Aplia or its principals in any way.

\section{AUTHOR INFORMATION}

Professor Pace has published one book and has over 25 articles published in peer-reviewed academic journals or presented at national conferences. His journal articles include publications in The Journal of Portfolio Management, Journal of Futures Markets, The Journal of Investing, Financial Services Review, Journal of Agricultural Economics, Global Finance Journal, Financial Practice and Education, International Journal of Business and The Journal of Small Business Finance. Since his appointment at UWF, he has received The University Distinguished Teaching Award and The E. W. Hopkins Faculty Development Award.

\section{REFERENCES}

1. Aplia. (n.d.). Retrieved June 2010, from http://aplia.com/company/downloads/ApliaCorpBG_0508.pdf

2. Bartlett, R. L., \& Feiner, S. F. (1992). Balancing the Economic Curriculum: Content, Method and Pedagogy. American Economic Review , 82 (2), 559-64.

3. Berk, J., \& DeMarzo, P. (2010). Corporate Finance : The Core (2 ed.). Prentice Hall.

4. Berk, J., DeMarzo, P., \& Harford, J. (2009). Fundamentals of Corporate Finance. Pearson Prentice Hall.

5. Besley, S., \& Brigham, E. F. (2010). CFIN 2010 . Cengage Learning.

6. Besley, S., \& Brigham, E. F. (2007). Essentials of Managerial Finance (14 ed.). Cengage Learning.

7. Brigham, E. F., \& Houston, J. F. (2009). Fundamentals of Financial Management (12 ed.). Cengage Learning.

8. Brooks, R. (2009). Financial Management: Core Concepts. Addison Wesley.

9. Brown, B. W., \& Liedholm, C. E. (2002). Can Web Courses Replace the Classroom in Principles of Microeconomics? American Economic Review , 92 (2), 444-448.

10. Caplan, A. J., \& Gilbert, J. (2008). 'D' is for dilly-dally? Applied Economics Letters, 15 (14), 1085 - 1088.

11. Ehrhardt, M. C., \& Brigham, E. F. (2011). Corporate Finance (4th Edition ed.). Cengage Learning.

12. Gitman, L. J. (2009). Principles of Managerial Finance (12 ed.). Addison Wesley.

13. Gitman, L. J. (2010). Principles of Managerial Finance, Brief (5 ed.). Addison Wesley.

14. Gitman, L. J., Joehnk, M. D., \& Smart, S. (2010). Fundamentals of Investing (11 ed.). Prentice Hall.

15. Goffe, W. L., \& Sosin, K. (2005, Summer). Teaching with Technology: May You Live in Interesting Times. Journal of Economic Education, 278-91.

16. Graham, J., Smart, S. B., \& Megginson, W. L. (2009). Corporate Finance : Linking Theory to What Companies Do. Cengage Learning.

17. Keon, A. J. (2010). Personal Finance: Turning Money into Wealth (5 ed.). Pearson.

18. Keown, A. J., Martin, J. H., \& Petty, J. W. (2011). Foundations of Finance (7 ed.). Pearson.

19. Madura, J. (2011). Personal Finance (4 ed.). Addison Wesley.

20. Megginson, W. L., \& Smart, S. B. (2009). Introduction to Corporate Finance (2 ed.). Cengage Learning.

21. Nguyen, T. T., \& Trimarchi, A. (2009, May 29-31). Promoting Student Engagement and Active Learning in Introductory Economics with Learning Technology. Paper Presented at the 43rd Annual Conference of the Canadian Economics Association. University of Toronto . 
22. Sosin, K., Blecha, B. J., Agarwal, R., Bartlett, R. L., \& Daniel, J. I. (2004). Efficiency in the Use of Technology in Economic Education: Some Preliminary Results. American Economic Review , 94 (2), 25358 .

23. Welch, I. (2009). Corporate Finance: An Introduction. Addison Wesley.

\section{NOTES}

